\title{
The Gradients of Informatization of Modern Court Proceedings in the Context of the Tasks and Principles of Civil Proceedings in the Russian Federation
}

\author{
Lilia Vladimirovna Voitovich*, Natalya Arkadevna Latysheva
}

Department of Civil Procedure Law, North-West Branch of the Russian State University of Justice in St. Petersburg, Russia

*Corresponding author.Email: voitovich@yandex.ru

\begin{abstract}
The content of domestic court proceedings, which is a special area of legal activity, is aimed at ensuring the administration of justice. At present, its traditional components are being substantially adjusted in connection with the implementation of the tasks of informatization in the activities of the state apparatus in the Russian Federation. The introduction of new technologies in the federal courts of general jurisdiction and in the federal arbitration courts, allowing the implementation of the established principles of the civil process, is carried out through the activities of the Federal State Budget Institution Information and Analytical Center of the Judicial Department. This institution provides automation and the creation of a single information space of courts, based on the tasks and requirements of the judicial community of Russia. Technological progress requires further improvement of the legislation on judicial activity regulating the functions of the court apparatus, including the norms of special federal constitutional laws. However, the best option for introducing these innovations should be a parallel change in the content of the principles of the civil process. In this regard, on the basis of a study of empirical material, it is proposed to expand the content of the current principles of civil procedural law, with the establishment of the possibility of using information and telecommunication technologies as fundamental ideas of a modern, accessible for citizens, civil proceedings. Keywords: civil litigation, litigation, judicial administration, informatization of judicial activity, e-justice, judges, court staff, Ethical Charter on the use of artificial intelligence in the judicial systems and the surrounding realities of 2018, the Concept of the information policy of the judicial system for 2020-2030

\section{INTRODUCTION}

It is important to timely study the possibilities of informatization in modern domestic court proceedings and judicial administration in connection with the emergence of new conceptual documents in the organization of judicial activity. This specialized state activity of court apparatus workers, carried out under the guidance of judges, is organized on the basis of the application of the tasks and principles formulated in the Civil Procedure

principles of openness, accessibility, informatization and transparency proposed for the introduction. The concept of the information policy of the judicial system for 2020 2030, which was approved by the Council of Judges of the Russian Federation on December 5, 2019, is a reporting point on the way to changing the content of some tasks and principles that apply in the framework of civil proceedings, as well as legislation on judicial activity. The quality of the implementation of the processes of informatization depends on the content of judicial proceedings and judicial administration, through which, inter alia, the principles of civil procedure are enforced.
\end{abstract} Code of the Russian Federation [1], the Code of Administrative Procedure of the Russian Federation [2] and the Arbitration Procedure Code of the Russian Federation [3]. The available scientific developments of both domestic and foreign researchers are related to the analysis of the implementation of existing, as well as the

\section{METHODOLOGY}

The following general scientific and private methods of cognition were used: comparison, analysis, generalization, 
induction and deduction, comparative legal method and the method of interdisciplinary legal research. A comparative legal analysis of the author's approaches to the content of the principles of civil procedure law using modern information and telecommunication systems is also used. The modeling in this study was based on the study of really existing processes in the field of judicial activity, including security (auxiliary character).

\section{RESULTS AND DISCUSSIONS}

The development of supranational justice also influences the process of establishing new forms of conducting court proceedings in the implementation of the tasks of the civil process. Changes related to the large-scale use of electronic technologies in the Russian Federation, including in judicial activities, are being implemented and will occur during the implementation of the Decree of the President of the Russian Federation dated May 9, 2017 No. 203 "On the Strategy for the Development of the Information Society in the Russian Federation for 2017 2030 years" [4]. The need to change the content of specialized Federal constitutional laws "On Arbitration Courts in the Russian Federation" (Articles 6 and 45) [5] and "On Courts of General Jurisdiction in the Russian Federation" (Articles 5 and 39) is defined in the context of the implementation of the ideas of judicial administration [6]. This improvement is necessary in order to specify the functions of the apparatus of these vessels in the context of priority development of electronic document and its' management.

Modern realities associated with the rapid development of information technology and electronic document management and documentation have a fundamental impact on the content of civil procedural law in the Russian Federation. In addition, informatization processes correlate with the general civilizational idea of the availability of information in the provision of electronic public services; many modern researchers, including A.A. Parthenchik, rightly pay attention to this [7]. Judicial clerical work, as an applied area of legal activity, allows for the resolution of various types of judicial civil conflicts. The necessary innovations should be introduced without technological backlogs in the conditions of the development of information technologies as part of the global global process, in legal proceedings, ensuring legal proceedings in the consideration of civil disputes. Judicial clerical work is an auxiliary judicial activity [8], or, of a security nature. This activity of the employees of the court apparatus to ensure legal proceedings, carried out under the guidance of judges [9], includes various directions, allowing to achieve the most effective interaction with civil society.
Thus, the further development of judicial clerical work within the framework of judicial administration takes place within the framework of the concept of "electronic government", the foundation of which is the idea of improving the quality and accessibility of public services [10]. The European Ethical Charter on the Use of Artificial Intelligence in the Judicial Systems and the Realities surrounding them [11], adopted on December 24, 2018 at the plenary meeting of the European Commission on the Effectiveness of Justice (hereinafter referred to as the Charter of 2018), allows the creation of development vectors during the formation of clerical aspects in the implementation of the tasks and principles of civil proceedings. The application of this Charter in individual states is of paramount importance [12]. The five principles for the use of artificial intelligence in legal proceedings, outlined in the 2019 Charter, generally correlate with the content of the principles of domestic civil proceedings, but using a legal clarification and interpretation tool. They also comply with the plans for a qualitative reform in the field of judicial proceedings - the Concept of the information policy of the judicial system for 2020 - 2030, approved by the Council of Judges of the Russian Federation on December 5, 2019. The principles of the Charter in 2018 can become indicators of further informatization of judicial activity when considering civil (administrative), arbitration cases in the Russian Federation. Ya.V. Antonov, summarizing the various approaches, designated the Recommendation on edemocracy of the Committee of Ministers of the Council of Europe CM / REC (2009) 1 as a reference point, adopted by the Committee of Ministers on February 18, 2009 at the 1049 meeting of deputy ministers, where ejustice is considered as a mechanism based on the use of information and communication technologies (ICT), which are used by all stakeholders in the process of administering justice in order to improve the efficiency and quality of public services [13]. Recommended for implementation in European countries, e-justice is seen as the most important sector of e-democracy. V.A. Ponomarenko noted that in general, the procedural legislation on electronic litigation is based on a doctrinal basis in the study of existing patterns in foreign countries [14]. At the same time, the impetus for a critical analysis of the changes taking place in the Russian Federation is a rather harsh assessment given by scientists in 2015: "Civilistic procedural science continues to gravitate towards the evolutionary path of development in the context of revolutionary social metamorphoses" [14].

The tasks of civil proceedings are the correct and timely consideration and resolution of civil cases. In the course of fulfilling this task, in accordance with Article 2 of the Code of Civil Procedure of the Russian Federation, the goals of protecting violated or disputed rights, freedoms 
and legitimate interests of citizens, organizations, as well as the rights and interests of the Russian Federation, its constituent entities, municipal entities, and other entities that are constituent entities must be achieved civil, labor or other legal relations. In addition, the current legislation of the Russian Federation clearly defines that civil proceedings should contribute to strengthening the rule of law and order, the prevention of offenses, the formation of a respectful attitude to law and court, and the peaceful settlement of disputes. The tasks of administrative proceedings, which relate to the content of civil proceedings in the framework of public relations, based on Article 3 of the Code of Administrative Procedure of the Russian Federation, are similar and have only some legal specificity. These include ensuring access to justice; protection of violated or contested rights, freedoms and legitimate interests of organizations; correct and timely review and resolution of cases; strengthening the rule of law and preventing violations; peaceful settlement of disputes. Article 2 of the Code of Arbitration Procedure of the Russian Federation, consisting of six, in many relevant tasks, has to ensure the availability of justice in the field of business and other economic activities, a fair public trial within a reasonable time. The principles of civil proceedings through which tasks are implemented are the fundamental principles of civil proceedings. They are also enshrined in the legislation, including the Constitution of the Russian Federation, are systemic in nature and form two groups: constitutional and functional principles of the civil process. The principles of legality, the administration of justice only by the court, the independence of judges, the accessibility of judicial protection, publicity, equality before the law and the court, equality and adversarial process of the parties, are fundamental constitutional principles of the civil process. Functional principles, or the basic principles of a civil process, include: a combination of dispositive and peer review of court cases, dispositiveness, orality and immediacy of the trial, as well as the continuity of the trial. The implementation of these principles is carried out in a civilized technological breakthrough. The principles that directly establish the use of information and telecommunication technologies that allow receiving, creating, placing and sending judicial documents in electronic format, in the procedural law and in the Code of Administrative Procedure of the Russian Federation are not established. Meanwhile, the content of domestic principles of civil procedural law, including taking into account the realities of more than five years of experience in the work of the Court of the Eurasian Economic Union (Court of the EAEU) and the development of the legal system at the supranational level [15], is upgraded.

Idea of T.V. Solovyova on fixing a new principle of the civil process - the principle of informatization has a high degree of relevance in the framework of this study [16]. The author notes that information technologies have found their implementation at many stages of civil proceedings at the present time, including: at the stage of initiating proceedings - part 4 of article 131 of the Code of Civil Procedure of the Russian Federation (filing a statement of claim in electronic form), at the stage of preparing the case for a court hearing - Part 2, article 152 of the Code of Civil Procedure of the Russian Federation (the possibility of using video conferencing systems), etc.

As follows from the official report of the Judicial Department at the Supreme Court of the Russian Federation for 2018, modern reality is characterized by the constant (round-the-clock) availability of information on the official websites of federal courts of general jurisdiction, magistrates, and federal arbitration courts [17]. A fairly accurate wording in such conditions is the assessment of the reality of V.V. Kotlyarova - "creating the conditions for the legal community to quickly receive information on court cases" [18]. However, how realistically do informatization resources become integral (mandatory, non-optional) technological components involved in civil procedural relations? The answer to this question lies in the plane associated with the mechanisms for the implementation of law. In the modern civil process, the use of ICT is formulated exclusively within the category of "opportunity", with the specification "if there is a technical possibility", with the exception of special relations related to the information content of the websites of ships on the Internet. For example, potentially any user of information whose rights are violated, including in the civil law sphere, can submit documents to initiate a trial electronically, if he has the skills and complies with the established requirements [19-21].

The use of information technology in the course of judicial proceedings while ensuring consideration of civil, administrative and arbitration cases, in a fairly generalized systematization, is carried out:

- when receiving documents in electronic form (including in the form of an electronic document) - article 131 Code of Civil Procedure of the Russian Federation, article 125 of the Code of Administrative Procedure of the Russian Federation; Article 125 of the Arbitration Procedure Code of the Russian Federation;

- in the conduct of registration work, in the formation of accounting and statistical cards in court cases, when the information entered in the data lines of cards through programming is automatically uploaded to the official websites of the courts on the Internet as data on cases considered in court ("information on the progress of cases");

- providing notifications and calls on the basis of SMS informing, e-mail, "other means of communication", posting information about the time and place of the 
meeting or performing a separate procedural action on the court's official website (article 113 of the Code of Civil Procedure of the Russian Federation, article 96 of the Code of Administrative Procedure of the Russian Federation, article 121 of the Arbitration Procedure Code of the Russian Federation);

- when providing video conferencing (article 155.1 of the Civil Procedure Code of the Russian Federation, article 142 of the Code of Administrative Procedure of the Russian Federation, article 153.1 of the Arbitration Procedure Code of the Russian Federation);

- in the process of audio and video recording (article 230 of the Civil Procedure Code of the Russian Federation, article 206 of the Code of Administrative Procedure of the Russian Federation, article 155 of the Arbitration Procedure Code of the Russian Federation);

- when sending copies of court decisions in electronic form, in a limited access mode on the court website, with attributes of enhanced qualified electronic signatures (Article 214 of the Civil Procedure Code of the Russian Federation, Article 182 of the Code of Administrative Procedure of the Russian Federation, Articles 15, 177 of the Arbitration Procedure Code of the Russian Federation);

- when arranging the placement of judicial acts, including depersonized ones, on the websites of federal courts of general jurisdiction and federal arbitration courts (article 15 of the Arbitration Procedure Code of the
Russian Federation; article 15 of the Federal Law of December 22, 2008 No. 262-FZ "On Access to Information" on the activities of courts in the Russian Federation ");

- when creating and sending in the established manner executive documents in electronic form (Article 428 of the Civil Procedure Code of the Russian Federation; Article 353 of the Code of Administrative Procedure of the Russian Federation; Article 319 of the Arbitration Procedure Code of the Russian Federation);

- in the formation of electronic archives of courts after the completion of court proceedings in the prescribed manner.

The determination of trends in the field of civil litigation is of practical importance in order to identify patterns in the field of informatization [22], including the use of video conferencing systems during the administration of justice. The procedural possibility of this type of participation in the court session is guaranteed: since 2013 under article 151.1 of the Code of Civil Procedure of the Russian Federation; since 2015, under article 142 of the Code of Administrative Procedure of the Russian Federation; since 2010 under article 151.1 of the Arbitration Procedure Code of the Russian Federation. Official statistical observation shows a relatively low percentage of demand for video conferencing systems in the modern civil process [23] (Table 1).

Table 1 The dynamics of the use of video conferencing systems in the courts of general jurisdiction of the Russian Federation when considering civil and administrative cases from 2017 to 2019

\begin{tabular}{|c|c|c|c|c|c|c|c|c|}
\hline \multirow[t]{2}{*}{ Year } & \multicolumn{2}{|c|}{$\begin{array}{c}\text { Total number of cases } \\
\text { examined under the Civil } \\
\text { Procedure Code of the } \\
\text { Russian Federation, Code } \\
\text { of Administrative } \\
\text { Procedure of the Russian } \\
\text { Federation }\end{array}$} & \multicolumn{2}{|c|}{$\begin{array}{l}\text { The total number of } \\
\text { cases of lawsuit } \\
\text { proceedings (the } \\
\text { amount of cases } \\
\text { examined, with the } \\
\text { exception of court } \\
\text { orders) }\end{array}$} & \multicolumn{2}{|c|}{$\begin{array}{c}\text { Number of cases } \\
\text { examined using video } \\
\text { conferencing }\end{array}$} & \multicolumn{2}{|c|}{$\begin{array}{c}\text { Relative rate of } \\
\text { video conferencing } \\
\text { use }(\%)\end{array}$} \\
\hline & $\begin{array}{c}\text { Civil } \\
\text { Affairs. }\end{array}$ & $\begin{array}{c}\text { Administrative } \\
\text { Affairs }\end{array}$ & $\begin{array}{l}\text { Civil } \\
\text { Affairs }\end{array}$ & $\begin{array}{l}\text { Administr } \\
\text { ative } \\
\text { Affairs }\end{array}$ & $\begin{array}{c}\text { Civil } \\
\text { Affairs }\end{array}$ & $\begin{array}{c}\text { Administrativ } \\
\text { e Affairs }\end{array}$ & $\begin{array}{l}\text { Civil } \\
\text { Affairs }\end{array}$ & $\begin{array}{l}\text { Adminis } \\
\text { trative } \\
\text { Affairs }\end{array}$ \\
\hline 2017 & $\begin{array}{c}13705 \\
059\end{array}$ & 4244158 & $\begin{array}{c}4014 \\
419\end{array}$ & 390919 & 6672 & 16379 & $0,16 \%$ & $4,19 \%$ \\
\hline 2018 & $\begin{array}{c}16469 \\
840\end{array}$ & 4329427 & $\begin{array}{c}3817 \\
067\end{array}$ & 435032 & 12089 & 20675 & $0,31 \%$ & $4,75 \%$ \\
\hline 2019 & $\begin{array}{c}18804 \\
923\end{array}$ & 5173637 & $\begin{array}{c}3658 \\
388\end{array}$ & 522559 & 23778 & 21273 & $0,65 \%$ & $4,07 \%$ \\
\hline
\end{tabular}


Based on the performed statistical analysis, the conclusion is verified that the video conferencing system is used when considering civil cases of lawsuit proceedings in a relatively small amount not exceeding $1 \%$. When considering legal cases under the Code of Administrative Procedure of the Russian Federation, the variation in the use of the video conferencing system increases, being within 4-5\%. At the same time, Russian courts are stepping up the pace of execution of court orders using a video conferencing system. 10,406 court orders in this form were executed in 2019, while most of them, 8,878, fell to the courts of general jurisdiction. Arbitration courts of the Russian Federation for the same period executed 895 court orders through a video conferencing system. Changes associated with the widespread use of electronic technologies, including in judicial activities, in the Russian Federation will occur during the implementation of Presidential Decree of May 9, 2017 No. 203 "On the Strategy for the Development of the Information Society in the Russian Federation for 2017 - 2030”. In this regard, the governance constants for the coming years should be the provision of the construction of an information society with a well-developed e-government infrastructure structure.

The content and interdependence of the constitutional principles on the accessibility of the right to judicial protection, publicity and, proposed for introduction, the principle of informatization, seems to be the direction of modern theoretical studies in law that will allow us to verify the probability and expediency of the independent existence of each of them (taking into account the conditions systemic action of the principles of the process). For example, I.A. Makarov and M.Sh. Tekeev believes that the principle of accessibility of justice in the field of business and other economic activities in the arbitration courts of the Russian Federation established in the Arbitration Procedure Code of the Russian Federation is relate to the development of information technology [24]. It should be assumed that the principle of informatization, in this case, by its substantial volume, is included by the authors in the general principle of accessibility, and, in fact, is a kind of organizational and technical mechanism that provides a procedural form of interaction between participants in legal proceedings.

The right to appeal to the court (Article 3 of the Civil Procedure Code of the Russian Federation, Article 4 of the Arbitration Procedure Code of the Russian Federation, Article 4 of the Code of Administrative Procedure of the Russian Federation) is an element of the implementation of the constitutional principle of the accessibility of the right to judicial protection. T.N. Neshataeva notes that the European principle of the right to a court is of a general and objective nature and includes the following elements of law: 1) to be heard (Case 75/77 (1978) ECR 897); 2) on the basis of equal rights of the parties (Case 114/76 (1977) ECR 1211); c) with legal representation (legal professional privilege "; d) a court acting on the basis of law; e) by a court acting impartially, fairly, independently in a certain procedure (Case 155/79 (1982) ECR 1575) [25]. T.N. Neshataeva, in connection with the above elements of the right to a court, refers to the decisions of European courts, the decisions of which note that "human rights and the rule of law become ephemeral without absolute principles of the right to a court" [25]. In modern reality, all of the above elements of the right to a court in the Russian Federation can be realized by participants in legal proceedings through ICT and the introduction of electronic justice. The need for a separate emphasis on the principle of informatization, in the form of an independent functional principle, will help accelerate the implementation of electronic technologies, including with the participation of artificial intelligence. In particular, if this principle is officially enshrined in the content of civil proceedings (Code of Civil Procedure of the Russian Federation), the costs of developing other legal documents will be minimized, including in connection with the elaboration of organizational measures related to resource and staffing of its implementation.

The composition of proposals that are directly close to the introduction of the principle of informatization is the announcement, in the course of future successes of electronic technologies in justice, of the transparency principle. Its introduction will become possible after this principle is recognized as international legal. K.K. Magomedova, a supporter of this innovation, considers the idea of transparency of justice as an element of the international standard of fair trial [26].

The transparency in justice in civil cases is considered by the author as "a qualitative sign of the administration of justice in these cases, which provides the opportunity for each interested person to receive information of interest to him on the organizational and procedural activities of the courts ..." [27]. K.K. Magomedova formulates the idea of the existence of three stages of a transparent model of justice in civil cases, which are differentiated by various forms of judicial notice. Taking into account this idea, addressed to the future, it is also necessary to ensure a clear distinction between the proposed principle of transparency and the current principles of transparency and access to justice. In connection with the study of this 
position, it is necessary to take into account the opinion of I.M. Divin, who expanded the scope of the contradictory conceptual apparatus to the triad: accessibility - openness - publicity. In particular, he came to the conclusion that accessibility is understood as the result of the effective implementation of the principle of publicity, concluding: "Justice can be regarded as accessible only when the conceptual foundations of the principle of publicity are fully implemented" [28].

Domestic researchers as the reporting point take the moment of the proclamation of the Concept of judicial reform in the RSFSR in 1991 summarizing the achievements, including those related to the organization and implementation of court proceedings in the pursuit of a single information space. So, A.V. Orlov, exploring the problems of ensuring access to justice, concluded that it was impossible to carry out genuine electronic justice, while recognizing the conditionally positive dynamics in the implementation of certain procedural actions by the example of organizing notifications to participants in proceedings by sending SMS notifications [29]. V.F. Borisova, on the contrary, noted the fact of "the most common function in the judicial system of electronic filing of documents with the court", which, from our point of view, is premature and is not confirmed by the official subject of the organization of court proceedings in the Russian Federation for most courts by the Judicial Department under the Supreme Court of the Russian Federation [30]. At the same time, V.F. Borisova about two groups of circumstances should be taken as fair, defined during the generalization of empirical material, which contribute to the development of electronic appeal to the court - these are factors of a material and technical nature (1), and insufficient development of the legal regulation of the procedural actions of persons who they carry out in virtual space (2) [31].

In connection with the need to change industry principles, one should also turn to the content of the Federal Constitutional Laws "On Courts of General Jurisdiction in the Russian Federation" and "On Arbitration Courts in the Russian Federation". Articles 5 and 6 of the laws under consideration that establish the principles of the activity of these courts do not contain any principles related to the use or fixing of priorities in the development of electronic justice in them. Meanwhile, e-justice, according to the 2018 Charter, should be considered as an integral segment of e-democracy in nation-states. The wording of the norms found in Articles 39 and 45 of the analyzed federal constitutional laws on the functions of the apparatus of federal courts of general jurisdiction and federal arbitration courts can be subjected to a similar correction. Among the regulated areas of activity, formed during the period of total paperwork, there is no support for the tasks of electronic justice while ensuring the power of the courts. It seems that the "Concept of the information policy of the judicial system for 2020-2030" is decisive in the development of concretized wording. In connection with the above, in order to accelerate the introduction of new technologies in the organization of judicial activity, it seems possible to amend the articles of the Federal Constitutional Law of February 7, 2011 No. 1-FKZ "On Courts of General Jurisdiction in the Russian Federation": 1) Supplement Article 5 with the paragraph: "Ensuring the use of digital and information technologies, including the use of cloud-based storage of information on judicial activity in the conditions of information openness and accessibility of justice for citizens and organizations".

2) Supplement article 39 with the paragraph: "Reception, preparation and sending of electronic documents (electronic images of documents), taking into account the rules of information security and the protection of personal data".

Similar changes should be made to the relevant articles 6 and 45 of the Federal Constitutional Law of April 28, 1995 No. 1-FKZ "On Arbitration Courts in the Russian Federation".

M.Yu. Vinokurov draws attention to the fact that the staff of the court apparatus must also ensure "information security of the judicial system" as an important aspect of the problem under consideration, taking into account the provision of legally protected personal rights in the Russian Federation, and further organizational planning should be carried out taking into account the Information Security Doctrine of the Russian Federation [32].

\section{CONCLUSION}

The legal uncertainty over the past few years in understanding e-justice has persisted. The principles of litigation enshrined in the current civil and arbitration procedural legislation, the Code of Administrative Procedure of the Russian Federation are currently insufficient for further transformations in informatization in courts and do not facilitate the widespread use of electronic justice elements.

The introduction of technological innovations in civil proceedings is ensured in the course of judicial proceedings by employees of the courts. The organization of judicial proceedings in the course of ensuring civil proceedings inevitably follows the principles of current procedural law. In recent years, in connection with the adoption of new conceptual documents, it is necessary to formulate new principles to ensure the regulation of relations in the field of information technology in the judiciary and the development of electronic justice.

The ongoing scientific discussion in understanding the basic terminological series of problems of informatization 
and e-justice contributes to the creation of a fundamental basis for updating legal regulation in the application of the principles of the civil process, including in the organization of judicial proceedings.

Achieving new prospects in judicial activity will be possible thanks to the consolidation of the functional principle of informatization and the introduction of electronic justice elements in the norms-principles of the Code of Civil Procedure of the Russian Federation, the Code of Administrative Procedure of the Russian Federation and the Arbitration Procedure Code of the Russian Federation.

The civil process is characterized by operational flexibility, rational and reasonable timeframes for implementation, speed of preliminary assessment, acceptance for consideration, as well as consideration of cases, as well as quality that reflects the possibility of independent prevention and reduction of excessive delay of the process [33]. These features form the dynamism of the civil process. In this regard, information technologies that ensure the introduction of e-justice elements will undoubtedly contribute to judicial optimization processes. To achieve this goal, amendments to the legislation are required, including the federal constitutional laws "On Courts of General Jurisdiction in the Russian Federation" and "On Arbitration Courts in the Russian Federation".

\section{REFERENCES}

[1] The Civil Procedure Code of the Russian Federation of November 14, 2002, No. 138-FZ (as amended on 04.24.2020), Meeting of the legislation of the Russian Federation, January 18, 2002, No. 46, Art. 4532 .

[2] The Code of Administrative Procedure in the Russian Federation dated March 3, 2015, No. 21-FZ (as amended on March 24, 2020), Meeting of the legislation of the Russian Federation, 09.03.2015, No. 10, Art. 1391.

[3] The Arbitration Procedure Code of the Russian Federation of July 24, 2002 No. 95-FZ (as amended on December 2, 2019). Collection of legislation of the Russian Federation, 07.29.2002, No. 30, Art. 3012.

[4] Decree of the President of the Russian Federation of 09.05.2017, No. 203, Available at:

http://www.kremlin.ru/acts/bank/41919.

[5] Federal constitutional law of April 28, 1995, No. 1-FKZ "On Arbitration Courts in the Russian
Federation" (as amended on July 18, 2019), Collection of legislation of the Russian Federation, 1995, No. 18, Art. 1589.

[6] Federal constitutional law of February 8, 2011, No. 1-FKZ "On courts of general jurisdiction in the Russian Federation" (as amended on March 6, 2019), Collection of legislation of the Russian Federation, 2011, No. 1, Art. 898.

[7] A.A. Parfenchyk, The role of legislation on accessibility of information in the provision of electronic public services, Available at: http://ncpi.gov.by/produkcia-i-uslugi/zhurnal-pravoby/arkhiv/vypusk-2-2020/.

[8] V.V. Ershov, Organization of judicial activity, RPMU, 2016.

[9] N.A. Latysheva, The concept and essential characteristics of judicial proceedings, Russian justice 2(94) (2014) 65-73.

[10] S.A. Sadikov, Yuridik fanda «Elektron hukumat» tushunchasi va tizim tarbikini tadkik etish masalasiga doir, Yuridik fanlar ahborotnomasi.

[11] European ethical Charter on the use of artificial intelligence in judicial systems and the realities surrounding them, European commission on the effectiveness of justice, Adopted at the 31st plenary meeting of the European commission on the effectiveness of justice, Strasbourg, 3-4 December 2018, Available at: https://rm.coe.int/ru-ethical-charteren-version-17-12-2018-mdl-06092019-2-/16809860f4.

[12] Ya.V. Antonov, Constitutional and legal prospects for the development of electronic justice in Russia, Administrator of the court 2 (2016) 10-15.

[13] R.A. Kurbanov, Artificial intelligence in dispensation of justice, Available at: http://ncpi.gov.by/produkcia-i-uslugi/zhurnal-pravoby/arkhiv/vypusk-2-2020/.

[14] V.A. Ponomarenko, Electronic civil proceedings in Russia: conceptual touches: a monograph, Moscow, 2015.

[15] Zh.N. Baishev, ЕАЭО құқығы дамуының өзекті мәселелері - «Еуразиялық экономикалық одақ туралы шартқа бес жыл: Соттың рөлі» 
халықаралық конференциясының нәтижелері, Кұқық және мемлекет 4(85) (2019) 1-18.

[16] T.V. Solovyova, Modernization of the principles of civil proceedings in the light of the reform of the judicial system, Arbitration and civil procedure 6 (2019) 8-13.

[17] The official website of the Judicial Department, Report for 2018, Available at:

http://www.cdep.ru/index.php?id=195.

[18] V.V. Kotlyarova, On the digitalization of the process of administration of justice, Arbitration and civil process 12 (2019) 46-49.

[19] Order of the Judicial Department at the Supreme Court of the Russian Federation dated December 27, 2016, No. 251 "On approval of the Procedure for submitting documents to the federal courts of general jurisdiction in electronic form, including in the form of an electronic document" (as amended on 08/27/2019).

[20] Order of the Judicial Department at the Supreme Court of the Russian Federation dated December 28, 2016, No. 252 "On approval of the Procedure for submitting documents to the arbitration courts of the Russian Federation in electronic form, including in the form of an electronic document (as amended on 02/20/2018).

[21] Order of the Judicial Department at the Supreme Court of the Russian Federation dated September 11, 2017, No. 168 “'On approval of the Procedure for filing magistrates with documents in electronic form, including in the form of an electronic document".

[22] N.A. Latysheva, Modern trends in civil judicial statistics in the courts of general jurisdiction of the Russian Federation as part of some relative indicators of administrative proceedings, Arbitration and civil procedure 6 (2019) 26-31.

[23] The official website of the Judicial Department, Section "Forensic Statistics", Available at: http://www.cdep.ru/index.php?id=79\&item=5083.

[24] I.A. Makarov, M.Sh. Tekeev, Accessibility of justice in arbitration courts: current issues of procedural regulation, Arbitration and civil procedure 2 (2020) 46-50.
[25] T.N. Neshataeva, The court and universally recognized principles and norms of international law, in: Anthology of scientific thought: On the 10th anniversary of the Russian Academy of Justice, Statute, 2008.

[26] K.K. Magomedova, To the discussion of the legal nature of transparency in justice in civil matters, Arbitration and civil process 1 (2020) 9-11.

[27] K.K. Magomedova, The problem of transparency in a civilistic procedural science and practice, Doct. Diss., Saratov, 2019.

[28] I.M. Divin, Openness of justice and modern information technology, Administrator of the court 3 (2016) 10 .

[29] A.V. Orlov, Ensuring access to justice: some new forms and organizational and legal prospects for their application, Administrator of the court 2 (2016) 7-9.

[30] Federal Law of February 8, 1998, No. 7-FZ “On the Judicial Department at the Supreme Court of the Russian Federation" (as amended on December 27, 2019), Collection of legislation of the Russian Federation, 1998, No. 2, Art. 223.

[31] V.F. Borisova, The implementation of the constitutional right to judicial protection in the aspect of the use of electronic technologies, Administrator of the court 2 (2019) 9.

[32] M.Yu. Vinokurova, Openness of justice in the context of ensuring the information security of the judicial system, Administrator of the court 1 (2017) 5256.

[33] E.B. Kireeva, The dynamism of the civil process, Bulletin of the civil process 2 (2018) 81-105. 